ISSN $1978-3000$

\title{
Palatabilitas Beberapa Hijauan Pakan pada Kelinci
}

\author{
Palatability of Several Forages on Rabbit
}

\section{Hidayat dan Tris Akbarillah}

\author{
Jurusan Peternakan Fakultas Pertanian Universitas Bengkulu
}

Jalan Raya Kandang Limun, Bengkulu. Telp. (0736) 2170 pst.219.

\begin{abstract}
This research was conducted to study the palatability of several forage easily found in rural area on rabbit. Two steps of trial were applied to test the palatability of forage, namely (1) free choice feeding and (2) voluntary feed intake. Tested forages were Cynodon spp., Calopogonium mucunoides, Glirisidia sepium, Manihot utilisima, and Imperata cylindrica. First step, 10 mature rabbits was placed in cages individually. Each of individual rabbit was offered 5 tested forages. This step was conducted for ten days. Each forage offered was weighed as well as residual forage at the following day. Water was offered ad libitum. Forages consumed was then converted to dry matter basis. Second steps, the best three of forage consumed on first trial were tested using Latin Square Crossover Experiment. Nine mature rabbit were divided in 3 groups, each of group consisted of 3 rabbit as replicates. Each rabbit was placed in an individual cage. Each group was offered different forage for a week, individually. Forage offered was rotate to other group weekly. Therefore each group of rabbit had been offered three kind of forage in three weeks. Parameter measured was dry matter consumed as first step. Free choice feeding of 5 forages offered showed that dry matter consumed of cynodon $37.5 \pm 1.6 \mathrm{~g}$, calopo $17.8 \pm 3.5 \mathrm{~g}$, cassava leaf $14.5 \pm 1.5 \mathrm{~g}$, satin tail $12.2 \pm 2.9 \mathrm{~g}$, and glirisidia $9.6 \pm 1.4 \mathrm{~g}$. In addition, second step resulted that the average voluntary feed intake of cynodon, calopo, and cassava leaf were $56.2 \mathrm{~g}, 33.9 \mathrm{~g}$, and $9.1 \mathrm{~g}$ respectively.
\end{abstract}

Key words: palatability, forage, rabbit

\begin{abstract}
ABSTRAK
Penelitian ini bertujuan untuk mengetahui palatabilitas beberapa hijauan pakan ternak yang banyak dijumpai sebagai pakan kelinci. Untuk mengetahui palatabilitas hijauan pakan pada kelinci dilakukan 2 (dua) tahapan percobaan, yaitu (1) pilihan pakan bebas (free choice feeding) dan (2) jumlah pakan yang dimakan secara sukarela (voluntary feed intake). Hijauan pakan yang dicoba pada tahap 1 adalah rumput Cynodon spp., Calopo (Calopogonium mucunoides), Glirisidia (Glirisidia sepium), pucuk daun ubi (Manihot utilisima), dan alang-alang (Imperata cylindrica). Tahap pertama: sepuluh ekor kelinci dewasa dikandangkan secara individu. Setiap kandang disediakan 5 jenis hijauan pakan tersebut di atas dengan jumlah yang diketahu dan tersedia tidak terbatas. Setiap hari ditimbang sisa pakan sehingga diketahui jumlah yang dikonsumsi. Konsumsi pakan per hari dikonversikan bahan kering. Untuk memenuhi kebutuhan air minum, air bersih disediakan sepanjang waktu. Pengamatan dilakukan selama 10 hari. Tahap kedua: hijauan bahan pakan yang digunakan adalah 3 (tiga) jenis hijauan pakan yang paling disukai. Rancangan percobaan yang digunakan adalah Latin Square Crossover Experiment dengan efek periode dan jumlah segi empat. Sembilan ekor kelinci dibagi menjadi 3 kelompok. Setiap ekor dalam kelompok diberi hijauan tertentu selama 1 minggu, kemudian diberi hijauan yang lain pada minggu berikutnya dan seterusnya sampai 3 minggu. dan variabel yang diamati adalah rerata jumlah bahan kering yang dikonsumsi dengan cara seperti pada tahap pertama. Percobaan tahap pertama dengan memberikan pilihan pakan secara bebas nilai rata-rata konsumsi bahan kering per hari dari 10 ekor kelinci adalah rumput cynodon 37,493 $\pm 1,591 \mathrm{~g}$, legum calopo $17,8 \pm 3,5 \mathrm{~g}$, daun singkong 14,5 $\pm 1,5 \mathrm{~g}$, alang-alang 12,2 $\pm 2,9 \mathrm{~g}$, dan glirisidia 9,6 $\pm 1,4 \mathrm{~g}$. Tahap kedua dengan percobaan konsumsi pakan secara sukarela dari 3 hijauan yang paling disukai pada tahap pertama menghasilkan konsumsi bahan kering rata-rata berbeda nyata antara pakan yang satu dengan yang lain. Rata-rata konsumsi bahan kering per hari masing-masing pakan adalah rumput cynodon $56,2 \mathrm{~g}$, legum calopo $33,9 \mathrm{~g}$, dan daun singkong 9,1 $\mathrm{g}$.
\end{abstract}

Kata kunci: palatabilitas, hijauan pakan, kelinci

\section{PENDAHULUAN}

Sampai saat ini sumber hijauan pakan ternak umumnya berasal dari kebun-kebun, pematang sawah, pinggir sungai, pinggir jalan, yang semua ini berkualitas rendah dengan kuantitas yang tidak kontinyu (Soejono et al., 1987). Hijauan pakan ternak yang banyak digunakan adalah rumput-rumputan (familia 
Gramineae) dan kacang-kacangan (familia Leguminoceae), dan juga sisa tanaman pertanian. Selain rumput unggul yang diintroduksikan, rumput alam mempunyai potensi yang sama untuk digunakan sebagai pakan ternak. Lebih dari itu, ketersediaannya tersebar luas sebagai rumput asli. Jenis rumput alam yang sering dijumpai antara lain adalah Axonopus compressus, Cynodon spp., Ileusne indica, Brachiaria mutica, Panicum spp., dan Paspalum conjugatum (Kehoe and Chang, 1987; Hidayat et al., 1992)

Hijauan pakan ternak termasuk dalam familia Leguminoceae yang sering dijumpai antara lain adalah Leucaena leucocephala, Gliricidia sepium, Sesbania grandiflora dan beberapa jenis legum yang digunakan sebagai tanaman penutup yang digunakan di perkebunan seperti Calopogonium mucunoides, Centrosema pubescens, Pueraria phaseloides (Rahman et al., 1985; Othman et al., 1985; Hidayat et al., 1992). Hijauan hasil sisa pertanian yang sering digunakan untuk pakan ternak antara lain jerami kacang tanah, jerami jagung, jerami sorghum, pucuk tebu, jerami padi, dan daun singkong (Reksohadiprodjo, 1984a).

Dalam penggunaan hijauan pakan ternak, palatabilitas merupakan salah satu kriteria sifat utam dalam pemilihan spesies hijauan pakan ternak untuk diintroduksikan pada suatu daerah, selain produktifitas, nilai gizi, dan lemampuan adaptasi terhadap keadaan tanah dan iklim setempat. Ivins (1952) mendefinisikan palatabilitas sebagai hasil keseluruhan faktor-faktor yang menentukan apakah dan sampai tingkat mana suatu pakan menarik bagi ternak. Dengan demikian, oleh McIlroy (1977) palatabilitas dapat dianggap sebagai penghubung antara hijauan dengan hewan yang memakannya, dan oleh beberapa ahli palatabilitas dianggap lebih penting dari pada nilai gizi. Palatabilitas bisa diuji dengan cara prasmanan (free choice feeding), yaitu dengan memberikan beberapa pilihan jenis pakan untuk suatu periode tertentu. Ternak diberi kebebasan memilih jenis pakan yang disukainya. McDonald et al. (1988) menjelaskan bahwa palatabilitas bahan pakan mempengaruhi voluntary feed intake (pakan yang dimakan oleh ternak secara sukarela) suatu ternak, tetapi palatabilitas yang digunakan untuk menjelaskan derajat kesediaan suatu bahan pakan untuk dipilih dan dimakan tidak sama dengan voluntary feed intake. Palatabilitas hanya melibatkan bau, rabaan, dan rasa.

Nilai produksi dari setiap bahan pakan tergantung pada jumlah bahan yang dimakan dan sejauh mana bahan pakan yang dikonsumsi tersebut mampu menyediakan energi, protein, mineral, dan vitamin. Dari kedua kondisi tersebut, jumlah bahan kering yang dimakan oleh ternak merupakan faktor paling penting dalam mengontrol nilai produksi suatu bahan pakan. Sangat jelas, apabila seekor ternak hanya bisa mengkonsumsi sejumlah kecil rumput maka produksinya akan rendah, tidak peduli apakah rumput tersebut mempunyai kandungan protein, energi tercerna, dan mineral yang tinggi (Minson, 1989).

Sebagai bahan pakan, hijauan mempunyai karakteristik tertentu yang mempengaruhi penampilannya dan hal ini bisa berpengaruh terhadap palatabilitasnya. Salah satu karakteristik tersebut adalah nilai nutrisi pakan seperti yang diekspresikan dalam komposisi kimia yang terkandung dalam bahan pakan tersebut. Hartadi et al. (1986) merangkum nilai beberapa hijauan pakan dan komposisi kimianya dan berikut adalah Tabel tentang komposisi hijauan pakan yang digunakan dalam percobaan.

Penelitian ini merupakan penelitian dasar untuk mengetahui palatabilitas beberapa hijauan pakan ternak yang banyak dijumpai sebagai pakan kelinci. Hijauan pakan tersebut adalah rumput Cynodon spp, Calopo (Calopogonium mucunoides), Glirisidia (Glirisidia sepium), pucuk daun ubi (Manihot utilisima), dan alang-alang (Imperata cylindrica)

Hasil penelitian ini diharapkan bisa memberikan informasi jenis hijauan pakan yang disukai kelinci dan bisa digunakan 
sebagai informasi dasar untuk penelitian daya cerna hijauan pakan yang disukai kelinci. Segi praktisnya, pengembangan ternak kelinci sebagai pabrik protein mini bisa lebih diarahkan ke daerah-daerah yang mempunyai potensi hijauan pakan yang melimpah dan disukai kelinci.

\section{MATERI DAN METODE}

Penelitian ini dilaksanakan di kandang peneliti, desa Bentiring. Untuk mengetahui palatabilitas hijauan pakan pada kelinci dilakukan 2 (dua) tahapan percobaan, pilihan pakan bebas (free choice feeding) jumlah pakan yang dimakan secara sukarela (voluntary feed intake). Hijauan pakan yang digunakan untuk penelitian ini adalah rumput Cynodon spp, Calopo (Calopogonium muconoides), Glirisidia (Glirisidia sepium), pucuk daun ubi (Manihot utilisima), dan alang-alang (Imperata cylindrica)

\section{Percobaan Tahap I. Pilihan Pakan Bebas (Free Choice Feeding).}

Sepuluh ekor kelinci dewasa dikandangkan (dikurung) secara individu. Setiap kandang (individu) disediakan 5 (lima) jenis hijauan pakan tersbut di atas dengan jumlah tidak terbatas. Masing-masing hijauan diberikan dengan jumlah yang diketahui (berat awal) dan sisanya (yang tidak dimakan) ditimbang, sehingga bisa diketahui berat masing-masing hijauan yang dikonsumsi oleh masing-masing individu kelinci. Penyajiannya disediakan terpisah antara jenis pakan yang satu dengan yang lain, tetapi masih dalam jangkauan kelinci (saling berdekatan), sehingga lebih mudah dalam pengontrolan sisa pakannya. Untuk mengetahui konsumsi bahan kering masing-masing hijauan pakan yang tersedia, hijauan pakan yang digunakan diambil contoh untuk dianalisa bahan keringnya untuk setiap hari pemberian. Untuk memenuhi kebutuhan air minum, air bersih disediakan sepanjang waktu. Pengamatan dilakukan selama 10 hari. Data konsumsi bahan kering yang didapat dihitung nilai reratanya dan diurutkan menurut preferensi kelinci dalam mengkonsumsi hijauan pakan yang disediakan.

\section{Percobaan Tahap II. Konsumsi Pakan Sukarela (Voluntary Feed Intake).}

Pada percobaan ini, hijauan bahan pakan yang digunakan adalah 3 (tiga) jenis hijauan pakan yang paling disukai. Rancangan percobaan yang digunakan adalah Latin Square Crossover Experiment dengan efek periode dan jumlah segi empat. Sembilan ekor kelinci yang terbagi menjadi 3 kelompok. Setiap ekor dalam kelompok diberi hijauan tertentu selama 1 minggu, kemudian diberi hijauan yang lain pada minggu berikutnya dan seterusnya sampai 3 minggu. dan variabel yang diamati adalah rerata jumlah bahan kering yang dikonsumsi dengan cara seperti pada tahap pertama.

Analisis data menggunakan analisis sidik ragam (Latin Square Crossover Experiment), apabila terdapat perbedaan dilanjutkan dengan uji beda antar rerata.

\section{HASIL DAN PEMBAHASAN}

Hasil percobaan pilihan pakan bebas (free choice feeding) pada tahap pertama terhadap 10 ekor kelinci yang diberi 5 macam hijauan yaitu pucuk daun singkong, calopo, alang-alang, rumput Cynodon, dan Glirisidia ditunjukkan pada Tabel 1.

Dari Tabel 2. tersebut dapat diketahui bahwa konsumsi bahan kering dari 5 hijauan yang disediakan untuk setiap individu ternak

Tabel 1. Komposisi kimia beberapa hijauan pakan dasar bahan kering (\%)

\begin{tabular}{lccccc}
\hline \hline \multicolumn{1}{c}{ Hijauan } & Protein Kasar & Serat Kasar & BETN & Ekstrak Eter & Abu \\
\hline Cynodon & 10,3 & 28,0 & 51,1 & 2,3 & 8,3 \\
Calopo & 14,7 & 34,0 & 40,3 & 3,0 & 8,0 \\
Daun singkong & 17,3 & 22,9 & 45,5 & 7,4 & 6,9 \\
Alang-alang & 5,4 & 35,4 & 48,2 & 1,0 & 10,0 \\
Glirisidia & 19,1 & 18,0 & 50,2 & 3,0 & 9,7 \\
\hline
\end{tabular}

Jurnal Sain Peternakan Indonesia Vol. 4, No 1. Januari - Juni 2009 
Tabel 2. Rerata konsumsi bahan kering (g) per hari untuk 5 macam hijauan yang disediakan secara bebas dan jumlah per hari untuk 5 macam hijauan pada setiap individu kelinci.

\begin{tabular}{crrrrrr}
\hline \hline No. & $\begin{array}{r}\text { Daun } \\
\text { Singkong }\end{array}$ & Calopo & Alang-alang & Rumput Cynodon & Glirisidia & $\begin{array}{r}\text { Total } \\
\text { per hari }\end{array}$ \\
\hline 1 & 15,59 & 16,54 & 10,07 & 37,89 & 10,33 & 90,42 \\
2 & 13,94 & 17,34 & 9,71 & 36,10 & 8,03 & 85,12 \\
3 & 17,15 & 18,96 & 11,17 & 35,31 & 9,66 & 92,25 \\
4 & 14,72 & 18,96 & 9,52 & 38,83 & 7,36 & 89,39 \\
5 & 14,12 & 18,96 & 10,99 & 38,98 & 10,23 & 93,28 \\
6 & 13,60 & 18,96 & 12,09 & 35,23 & 8,51 & 88,39 \\
7 & 14,64 & 18,96 & 10,02 & 36,38 & 9,85 & 89,85 \\
8 & 13,77 & 20,37 & 14,47 & 39,26 & 9,18 & 97,05 \\
9 & 15,68 & 8,42 & 15,94 & 38,98 & 10,62 & 89,64 \\
10 & 11,60 & 20,37 & 17,59 & 37,97 & 12,15 & 99,68 \\
\hline Jumlah & 144,81 & 177,84 & 121,57 & 374,93 & 95,92 & 915,07 \\
\hline Rerata & 14,481 & 17,784 & 12,157 & 37,493 & 9,592 & 91,507 \\
\hline Std. dev & 1,486 & 3,492 & 2,855 & 1,591 & 1,390 & \\
\hline
\end{tabular}

menunjukkan bahwa rumput cynodon paling disukai dan berturut-turut diikuti calopo, daun singkong, alang-alang, dan yang paling kurang disukai adalah glirisidia.

Kemudian, pada percobaan tahap kedua dengan menggunakan metoda konsumsi pakan sukarela (voluntary feed intake) pada 3 jenis hijauan yang paling disukai pada tahap pertama terlihat bahwa rata-rata konsumsi bahan kering setiap jenis hijauan menunjukkan perbedaan yang sangat nyata antara hijuan satu dan lainnya. Nilai rata-rata konsumsi bahan kering per hari untuk masingmasing hijauan yang diberikan secara tunggal dan dikonsumsi secara sukarela oleh ternak tercatat rumput Cynodon 56,22 g, Calopo 33,69 $\mathrm{g}$, dan daun singkong 9,09 g (Tabel 3).

Dari hasil dua percobaan tersebut di atas terlihat bahwa ternak kelinci mempunyai tingkat preferensi terhadap jenis hijauan. Palatabilitas hijauan pakan dipengaruhi beberapa faktor, antara lain yang paling menonjol adalah kandungan zat gizi dan material lain seperti racun, aroma, dan bahan lain. McDonald et al. (1988) menjelaskan bahwa palatabilitas bahan pakan mempengaruhi voluntary feed intake (pakan yang dimakan oleh ternak secara sukarela) suatu ternak, tetapi palatabilitas yang digunakan untuk menjelaskan derajat kesediaan suatu bahan pakan untuk dipilih dan dimakan tidak sama dengan voluntary feed intake. Palatabilitas hanya melibatkan bau, rabaan, dan rasa. Glirisidia kurang disukai oleh kelinci diduga lebih disebabkan oleh aromanya yang kurang disukai oleh ternak apabila diberikan dalam bentuk segar. Beberapa praktisi menyarankan dalam penggunaan daun glirisidia sebagai pakan ternak hendaknya dilayukan terlebih dahulu untuk menghilangkan aroma yang tidak disukai oleh ternak. Lain halnya dengan alangalang, hijauan ini mempunyai kandungan serat kasar dan lignin yang tinggi, sehingga kurang disukai oleh kelinci yang termasuk hewan monogastrik. Penampilan hijauan pakan seperti yang ditunjukkan derajat kekasaran akan berpengaruh terhadap palatabilitas. Derajat kekasaran hijauan barangkali berhubungan dengan kandungan serat di dalamnya. Serat kasar didalam hijauan yang biasanya dalam bentuk selulosa selalu berhubungan dengan kandungan lignin. Kelinci sebagai ternak monogastrik tidak menghasilkan enzim yang mampu mencerna selulosa. Hal ini mungkin yang menjadi pembatas dalam kemauannya untuk memilih alang-alang, apalagi ada kandungan lignin di dalamnya. Dengan adanya beberapa pilihan pakan, ternak mendapatkan kesempatan untuk memenuhi atau mencukupi kebutuhannya sejauh bahan-bahan pakan bisa menyediakan apa yang mereka butuhkan, seperti energi, protein, dan zat gizi lainnya

Tiga jenis hijauan yang paling disukai, daun singkong merupakan hijauan yang kurang disukai. Hal ini terbukti dengan konsumsi bahan keringnya yang kecil dan 
Tabel 3. Latin Square Crossover Experiment untuk konsumsi pakan bebas (voluntary feed intake) dasar bahan kering (g) dengan pemberian 3 macam hijauan pakan.

\begin{tabular}{|c|c|c|c|c|}
\hline \multicolumn{5}{|c|}{ PERIODE } \\
\hline Kelinci & 1 & 2 & 3 & Total \\
\hline 1. & $56,35(\mathrm{R})$ & $10,51(S)$ & $44,95(\mathrm{C})$ & 111,81 \\
\hline 2. & $30,68(C)$ & $59,03(\mathrm{R})$ & $4,03(S)$ & 93,74 \\
\hline 3. & $4,03(\mathrm{~S})$ & $44,95(\mathrm{C})$ & $59,03(\mathrm{R})$ & 108,01 \\
\hline Total & 91,06 & 114,49 & 108,01 & 313,56 \\
\hline 4. & $35,93(\mathrm{C})$ & $53,14(\mathrm{R})$ & $9,82(S)$ & 98,89 \\
\hline 5. & $9,82(\mathrm{~S})$ & $32,95(\mathrm{C})$ & $53,14(\mathrm{R})$ & 95,91 \\
\hline 6. & $55,94(\mathrm{R})$ & $10,83(\mathrm{~S})$ & $32,95(\mathrm{C})$ & 99,72 \\
\hline Total & 101,69 & 96,92 & 95,91 & 294,52 \\
\hline 7. & $7,89(S)$ & $11,18(\mathrm{C})$ & $60,09(\mathrm{R})$ & 79,16 \\
\hline 8. & $60,09(\mathrm{R})$ & $12,44(\mathrm{~S})$ & $34,80(\mathrm{C})$ & 107,33 \\
\hline 9. & $34,80(\mathrm{C})$ & $49,13(\mathrm{R})$ & $12,44(\mathrm{~S})$ & 96,37 \\
\hline Total & 102,78 & 72,75 & 107,33 & 282,86 \\
\hline Total perlakuan & 505,94 & 303,19 & 81,81 & 890,94 \\
\hline Rerata & $56,216^{a}$ & $33,688^{b}$ & $9,09 \mathrm{C}$ & \\
\hline
\end{tabular}

Keterangan: $\quad(\mathrm{R})$ : rumput cynodon; $(\mathrm{C})$ : legum calopo; (S) : daun singkong

diduga karena ternak kelinci yang diberi daun singkong secara tunggal akan membatasi konsumsinya sebagai akibat kandungan sianida dalam hijauan tersebut. McDonald (1988) menerangkan bahwa yang mempengaruhi voluntary feed intake antara lain faktor-faktor fisiologis, seperti keterbatasan saluran pencernaan dalam mengakomodasi bahan pakan yang berhubungan dengan kebutuhan energi suatu ternak. Hal lain yang mungkin mempengaruhi adalah defisiensi zat gizi tertentu dalam bahan pakan tersebut dan kemuampuan ternak dalam melakukan sensor pakan. Reksohadiprodjo (1984b) menjelaskan bahwa gangguan-gangguan yang bisa menyebabkan penyakit produksi ternak antara lain bisa disebabkan oleh bahan pakan yang mengandung zat-zat yang mempunyai sifat toksik, walaupun tingkatannya sangat bergantung dengan jenis pakannya. Singkong termasuk tanaman yang mengandung asam sianida. Glukosida yang mengandung $\mathrm{HCN}$ dalam singkong disebut linamarin. Dengan adanya HCN yang terkandung dalam daun singkong dan kemampuan ternak dalam melakukan sensor, konsumsi pakan bebasnya akan rendah seperti halnya pada hasil percobaan.

\section{SIMPULAN}

Dari kedua percobaan tersebut diatas terlihat bahwa rumput merupakan jenis hijauan pakan ternak yang paling disukai dari kelima jenis hijauan yang dicoba. Berturutturut hijauan yang paling disukai pada percobaan pilihan pakan bebas adalah rumput cynodon, legum calopo, daun singkong, alangalang, dan glirisidia. Konsumsi pakan bebas yang dicoba pada rumput cynodon, legum calopo, dan daun singkong menunjukkan bahwa rumput dikonsumsi lebih banyak dibandingkan legum calopo dan daun singkong. Legum Calopo dikonsumsi lebih banyak dibandingkan daun singkong. Untuk meningkatkan nilai gizi pakan, rumput bisa diberikan bersama-sama dengan legum calopo yang juga disenangi kelinci. Walaupun demikian, kalau diberikan secara bersamasama atau disusun suatu ransum yang rasional, tidak menutup kemungkinan jenis jenis hijauan pakan yang kurang disenangi masih bisa digunakan sebagai pakan.

\section{DAFTAR PUSTAKA}

Anonimus. 1988a. Ikhtisar Statistik Indonesia 1988. BPS. Jakarat. 
.1988b. Laporan Utama Menyongsong Pelita V Bidang Perunggasan. Poultry Indonesia No.108/Th. IX. Jakarta.

Hartadi, H., Reksohadiprodjo,S dan Tillman, A.D. 1986. Tabel Komposisi Pakan Untuk Indonesia. GadjahMada University Press. Yogyakarta.

Hidayat. Brata, B., Akbarillah, T., Soetriyono, Sukiyono, K., dan Arnofwardin. 1992. Potensi Tanaman Rumput dan Legum di antara tanaman karet sebagai pakan ternak. Laporan Penelitian. Balai Penelitian Universitas Bengkulu.

Kehoe, M.M. and Chan, L.C. 1987. Buffalo Draught Power on Oil Palm Estate. The Incorporated and Society of Planters. Kuala Lumpur.

McDonald, P. Edwards, R.A., and Greenhalgh, J.F.D. 1988. Animal Nutrition. Longman. London.

McIlroy, R.J. 1977. Pengantar Budi Daya Padang Rumput Tropika. Pradnya Paramita. Jakarta.

Minson, D.J. 1990. The chemical composition and nutritive value of tropical grasses.
In: P.J. Skerman and F. Riveros: Tropical Grasses. FAO. Rome.

Othman, A., Shukri, H.I.M., Wong, C.C., Eng, P.K., dan Chen, C.P. 1985. Integrasi lembu di ladang-ladang perkebunan kelapa sawit. Teknol. Ternakan. Jil. 1. Bil. 2. pp.105-109.

Rahman, M.Y.A. dan Khusahry, M.Y.M. 1985. Integrasi kambing dan biri-biri dengan tanaman utama. Teknol Ternakan Jil. 1. Bil. 2 pp. 111-120.

Reksohadiprodjo, S. 1984. Bahan Makanan Ternak Limbah Pertanian dan Industri. BPFE. Yogyakarta.

1984. Penyakit-Penyakit Produksi Ternak. BPFE. Yogyakarta.

Soejono, M. Utomo, R., dan Widayantoro. 1987. Peningkatan Nilai Nutrisi Jeraami Padi dengan Berbagai Perlakuan. Dalam Soejono, M., Musofie, A., Utomo, R., Wardhani, N.K., dan Schiere, J.B. (eds.): Limbah Pertanian Sebagai Pakan dan Manfaat Lainnya. Proceedings: Bioconversion Project Second Workshop on Crop Residues for Feed and Other Purposes. Grati. pp 21-35. 